\title{
Perception of Local Communities Towards the Conservation Terubok
}

\author{
Nur Athirah Bakeri \\ Faculty of Economics and Business \\ Universiti Malaysia Sarawak, 94300, Kota Samarahan, Sarawak, Malaysia \\ E-mail: 17020071@siswa.unimas.my \\ Dayang Affizzah Awang Marikan \\ Faculty of Economics and Business \\ Universiti Malaysia Sarawak, 94300, Kota Samarahan, Sarawak, Malaysia \\ E-mail: amdaffizah@unimas.my \\ Amin Mahir Abdullah \\ Department of Agriculture \\ Universiti Putra Malaysia, Malaysia \\ E-mail: amahir@upm.edu.my
}

Received: Aug. 7, 2019 Accepted: Aug. 28, 2019 Online published: Sep. 10, 2019

doi:10.5296/jpag.v9i3.15232ＵRL: https://doi.org/10.5296/jpag.v9i3.15232

\begin{abstract}
Terubok is one of the famous, important commercially fish in Malaysia and has high economic value which only can be found in Sarawak rivers. However, this species has been threatened in the past 15 years due to heavy exploitation. Hence, this study was done to examine the perceptions of local in conserving and sustaining the terubok population. An attitudinal study is increasingly being adopted as tools for evaluating public understanding, acceptance and the impact of conservation interventions. This study examines the perception and views of local community towards the dynamic resources, government intervention, unique features and livelihood sustainability which acts as a basis on conserving terubok. The findings of these studies show that almost all of the respondents show a highly positive
\end{abstract}




\section{Macrothink}

Journal of Public Administration and Governance

ISSN 2161-7104

2019, Vol. 9, No. 3

attitude towards conserving terubok. Local community are really well aware with the importance of terubok. Hence, this study has proof that the local community has a positive attitude towards conserving terubok.

Keywords: descriptive analysis, natural resources, conservation

\section{Introduction}

The tropical shad of genus Tenualosa or locally known as Terubok fish are important estuarine fishes both commercially and culturally in many Asian countries including Malaysia. Worldwide, there are five types of genus Tenualosa that can be found which is Tenualosa toli, Tenualosa macrura, Tenualosa illisha, Tenualosa revesii and Tenualosa thibaudaui (Blaber, Milton, Pang, Wong, Boon, Nyigo \& Lubim, 1996). However, only two species can be found in Malaysia which is Tenualosa toli and Tenualosa Macrura. Tenualosa toli can be found only in the estuaries and adjacent coastal of Sarawak which comprises the estuaries of Batang Sadong, Batang Lupar, Batang Saribas and Batang Lassa (Rajali, 1991; Philip, 2001; Blaber, Milton, Chenery \& Fry, 2003) (Figure 1). However, nowadays, terubok fish are very limited and depleting in coastal waters of Sarawak. The population of terubok is being threatened because of the over-exploitation (Rahim, Tumiran, Yuzine \& Husaini, 2014).

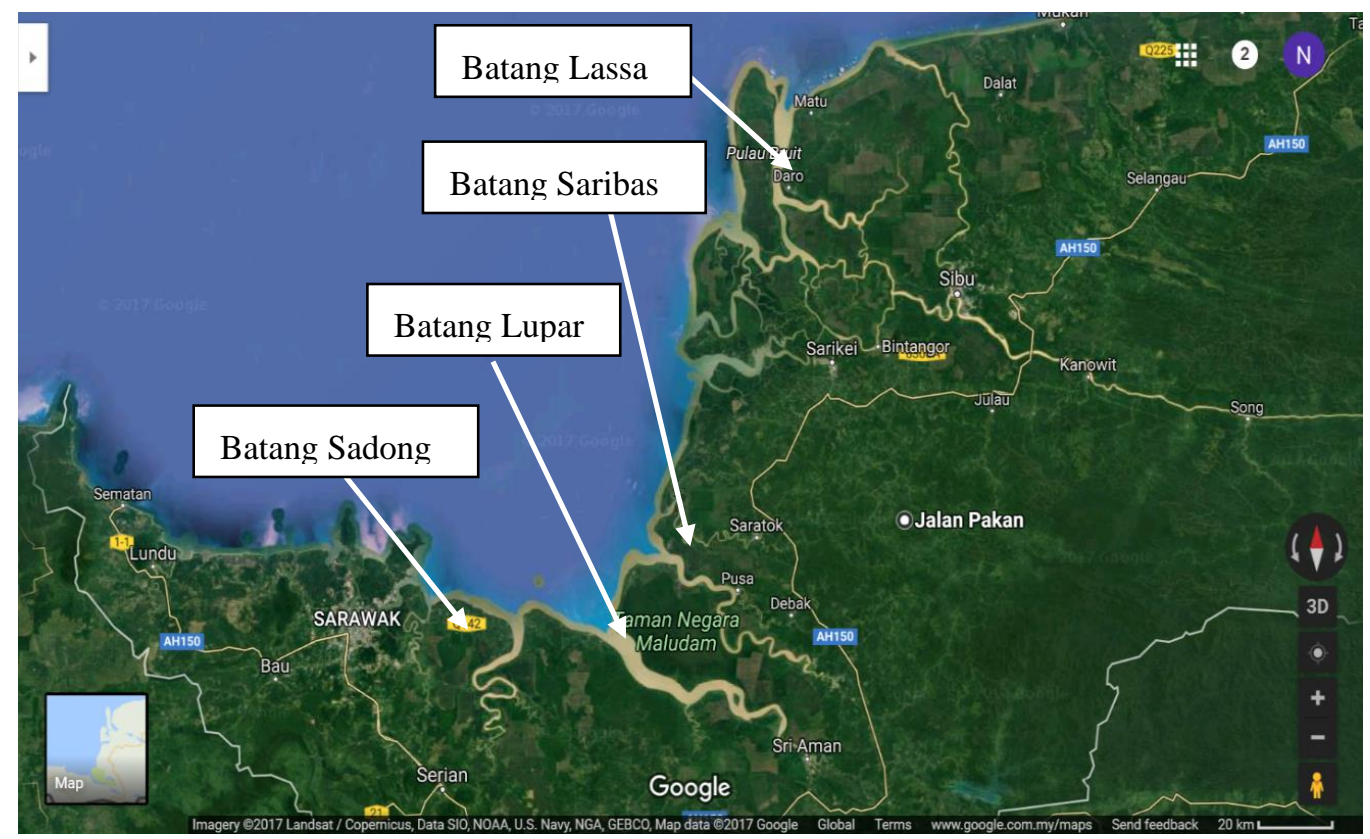

Figure 1. Maps of "Core Terubok Sungai (tenualosa toli) Area” in Sarawak

Source: Google Maps (2019)

Terubok is being exploited especially for its roe and meat which the spawning adult fish is targeted. The number of local terubok are still very limited and very difficult to obtain. Due to the high demand of terubok in Sarawak, many imported terubok that came from India and Myanmar entering the market. Terubok provides a good illustration of a public good for natural ecosystems that are currently under tremendous pressures. This study is mainly focusing on tenualosa toli or locally known as river terubok because nowadays terubok are 
scarce and yet it has a high market value. Terubok has socio-cultural value that community are not aware with the significant of terubok. Terubok is one of the famous and important commercially fish in Malaysia and it is also famous among tourist with the name of terubok ikan masin, where it is highly demanded in local market for its meat and egg (Blaber et al., 2003). Tourist especially came from West Malaysia would not miss the opportunity to buy it. While, tenualosa macrura or locally known as sea terubok are less favorable because of the taste of its meat are less tasty than river terubok.

\section{Methods}

The study was conducted in Kuching area using a random sampling. 1300 respondent were interviewed and only 1203 are used for the purpose of this analysis. The potential respondents were asked about their perception towards conserving terubok. Potential respondents were approached and asked if they were willing to participate in this study. The interviews were done in face-to-face approach to the respondents. The questionnaire was written in Bahasa Melayu because all respondents are mostly not using English as their mother tongue language. The first part of the questionnaire asking respondent with a general ("warm-up") question comprises of background of the study. This aimed at making the respondent comfortable with participating in the survey and answering questions. Respondents level of knowledge about the current status of terubok in Sarawak river was also assessed. Respondents were also asked to state their perception towards the conservation of terubok. Last but not least, the information regarding respondents' socio-economics and demographic characteristics such as age, gender, occupation, education level and average monthly income will be asked in the last part of the questionnaire. The data obtained from the interview were analyzed using the SPSS statistic version 22. Descriptive analysis such as mean and frequency were used to obtain information about the socio demographic, economic profiles, and respondent's perception.

\section{Results and Discussion}

\subsection{Demographic Characteristics of the Respondents}

Table 1 displays the summary of the respondents' profiles. The minimum and maximum age of respondents is at 18 to 69 years old respectively. In term of income, the lowest and highest of income is at RM100 and RM15,000 respectively. By gender, the majority of respondents were male $(55.6 \%)$. Moreover, almost all of the respondents are employed $(83.3 \%)$ and the remaining are self-employed (11.4\%), pensioner $(2.6 \%)$ and unemployed (2.7\%). In term of education background, most of the respondents had completed tertiary education $(96.5 \%)$ while the others are only completed primary $(0.3 \%)$ and secondary $(3.1 \%)$ education level. 
Table 1. Profile of respondents

\begin{tabular}{cccccc}
\hline Variable & & Frequency & $\%$ & Min & Max \\
\hline Age & & & & 18 & 69 \\
Income & & & & 100 & 15000 \\
Gender & Male & 532 & 55.6 & & \\
& Female & 424 & 44.4 & & \\
Employment status & Employed & 796 & 83.3 & & \\
& Self-employed & 109 & 11.4 & & \\
& Pension & 25 & 2.6 & & \\
& Unemployed & 26 & 2.7 & & \\
Education & Primary & 3 & 0.3 & & \\
& Secondary & 30 & 3.1 & & \\
& Tertiary & 923 & 96.5 & & \\
& &
\end{tabular}

\subsection{Descriptive Analysis}

Table 2. Perception towards the Dynamic Resources

\begin{tabular}{|c|c|c|c|c|}
\hline & Statements & Agree & Disagree & $\begin{array}{c}\text { No } \\
\text { Comment }\end{array}$ \\
\hline a. & $\begin{array}{l}\text { Terubok fish industry can offer a high yield to } \\
\text { Sarawakians }\end{array}$ & 82 & 5.1 & 13 \\
\hline b. & $\begin{array}{l}\text { Terubok fisheries can expand the market and } \\
\text { enhance the international marketing network }\end{array}$ & 82.8 & 4.8 & 12.4 \\
\hline c. & $\begin{array}{l}\text { Terubok fisheries can increase the capacity of } \\
\text { local capital with private investment in the } \\
\text { fisheries sector }\end{array}$ & 78 & 5.8 & 16.2 \\
\hline d. & $\begin{array}{l}\text { Terubok fisheries can promote Research and } \\
\text { Development (R\&D) programs }\end{array}$ & 88.1 & 4.8 & 15.2 \\
\hline e. & $\begin{array}{l}\text { Terubok fisheries encourage the development of } \\
\text { industries related to tourism, entrepreneurship, } \\
\text { boat manufacturing, fishing equipment etc }\end{array}$ & 81.8 & 5.2 & 13.1 \\
\hline f. & $\begin{array}{l}\text { Terubok fisheries can generate a } \\
\text { homestay-based tourism industry }\end{array}$ & 70.2 & 8 & 21.9 \\
\hline g. & $\begin{array}{l}\text { Terubok fisheries help in expanding the relevant } \\
\text { economic chains such as tourism, services, } \\
\text { transportation etc }\end{array}$ & 83.1 & 12.3 & 4.6 \\
\hline
\end{tabular}


Clearly, the dynamic natural resources of terubok is viewed positively by a majority of respondents. Table 2 shows that $88.1 \%$ of the respondents which is the highest of all agree about the statement of terubok fisheries can promote research and development (R\&D) programs. More R\&D should be done since terubok are one of the famous products among tourist that came to Sarawak in order to promote economic growth through innovations and increase the productivity or new product lines of terubok. And the followed by $83.1 \%$ of respondents are agreed with the statement of terubok fisheries help in expanding the relevant economic chains such as tourism, services, transportation and etc. Less of them $70.2 \%$ agrees with the statement "terubok fisheries can generate a homestay-based tourism industry". $21.9 \%$ are giving a no comment response with the statement.

Table 3. Perception towards Government Intervention

\begin{tabular}{|c|c|c|c|c|}
\hline & Statements & Agree & Disagree & $\begin{array}{c}\text { No } \\
\text { Comment }\end{array}$ \\
\hline a. & $\begin{array}{l}\text { Terubok should be protected for future } \\
\text { generation }\end{array}$ & 85.8 & 3.2 & 11 \\
\hline b. & Capture the small terubok are an offence & 59 & 11.9 & 29.1 \\
\hline c. & $\begin{array}{l}\text { Popularity of terubok has indirectly threatened } \\
\text { its reproduction }\end{array}$ & 60.7 & 15.1 & 24.3 \\
\hline d. & $\begin{array}{l}\text { The efforts of government to conserve terubok } \\
\text { can ensure the sustainable of terubok fishery }\end{array}$ & 86.5 & 2.7 & 10.8 \\
\hline e. & $\begin{array}{l}\text { Fishing during the non-seasonal of terubok } \\
\text { should be prosecuted to prevent the species from } \\
\text { extinct }\end{array}$ & 63.4 & 11.3 & 25.2 \\
\hline f. & $\begin{array}{l}\text { By preserving the stock of terubok, it can ensure } \\
\text { the survival of future fisheries by future } \\
\text { generations }\end{array}$ & 80.2 & 5.1 & 14.9 \\
\hline g. & $\begin{array}{l}\text { Monitoring for the catches of terubok are } \\
\text { essential }\end{array}$ & 80.6 & 4.3 & 15.2 \\
\hline h. & All terubok fishing areas should be monitored & 82.3 & 3.9 & 13.8 \\
\hline
\end{tabular}

About $86.5 \%$ of respondents believe that the effort of government to conserve terubok can ensure the sustainable of terubok fishery. Government plays a significant role in managing and protecting the natural resources including terubok. It helps in promoting the biodiversity for a healthy and functional ecosystem. The effort that being taken by government to conserve terubok can enriches the natural habitat of terubok and keep the nature's balance. 
$86.5 \%$ of respondent's response agree with the statement terubok should be protected for future generations. The conservation of endangered species like terubok is important for human as well. A well-balanced ecosystem purifies the environment, giving us clean air to breathe and a healthy water system to support diverse marine life. However, less (59\%) of them are response agree with the statement "capture the small terubok are an offence". $29.1 \%$ of them response "no comment" with the statement.

Table 4. Perception towards Unique Features

\begin{tabular}{lccc}
\hline Statements & Agree & Disagree & $\begin{array}{c}\text { No } \\
\text { Comment }\end{array}$ \\
\hline $\begin{array}{l}\text { a. Terubok are well known to tourists } \\
\text { b. Terubok contributes significantly to the Sarawak } \\
\text { economy }\end{array}$ & 91.3 & 2.9 & 5.9 \\
$\begin{array}{l}\text { c. Terubok are favorite of many } \\
\text { d. Terubok have high protein content }\end{array}$ & 88.2 & 2.5 & 13.1 \\
e. Terubok produces high nutritional value & 75.8 & 3.3 & 20.9 \\
\hline
\end{tabular}

Terubok has so many features that attract more tourist came to Sarawak. Almost all $(91.3 \%)$ of the respondents are agree with the statement of "terubok are well known to the tourist". Which means that, terubok are extremely popular among tourist that came to Sarawak. In Kuching, terubok are highly valued among visitors although terubok has many fine bones, the slight greasiness of its flesh makes it very tasty. Terubok, especially its eggs are highly priced and frequently purchased as gifts.

Table 5. Perception towards Livelihood Sustainability

\begin{tabular}{lccc}
\hline Statements & Agree & Disagree & $\begin{array}{c}\text { No } \\
\text { Comment }\end{array}$ \\
\hline $\begin{array}{l}\text { a. Catching terubok is the main source of income } \\
\text { for the fisherman }\end{array}$ & 78.6 & 7.3 & 14.1 \\
$\begin{array}{l}\text { b. Selling fish is the main source of income for } \\
\text { terubok seller }\end{array}$ & 84.5 & 5.2 & 10.3 \\
$\begin{array}{l}\text { c. Terubok industry can provide more employment } \\
\text { opportunities to the locals }\end{array}$ & 77.9 & 6.2 & 16 \\
\hline
\end{tabular}

About $84.5 \%$ of respondents are response agree with the statement of "selling fish is the main source of income for terubok seller". Over the years, terubok has been attracting a good 
number of customer and has brought about newcomers into the business which leads to the wider source of supply and demand. Followed by $78.6 \%$ of respondents are agree with the statement "catching terubok is the main source of income for the fisherman". Terubok fish is an estuaries fish that is significant among local fishermen because of the high commercial value and it also constitute to source of income for terubok fishermen during its catching season.

\section{Conclusion}

This study attempts to view the local community's perception towards the conservation of terubok. The findings revealed that majority of the population view on conserving terubok are in highly positive manner. This indicates that community in Sarawak are well aware with the importance of conserving terubok. They believe that, if there is no proper intervention to be implemented on conserving terubok, it will extinct and forgotten by time. Moreover, from conserving terubok, they can help the local communities indirectly who earn income from terubok. From here, it is crucial to have an awareness among the local communities on how importance of conserving terubok. This study has proof that the local community has a positive attitude towards conserving terubok. Hence, it is our responsibility to help and protect these animals in order future generations can grow and thrive, which help out future generations will be blessed to enjoy and share their lives with these animals. Future studies can explore more on the perception of conserving terubok particularly in all division of Sarawak to get a wider picture of the issues and solutions.

\section{Acknowledgement}

The research is financed by Ministry of Higher Education from the project of Trans Disciplinary Research Grant Scheme.

\section{References}

Blaber, S. J., Milton, D. A., Pang, J., Wong, P., Boon-Teck, O., Nyigo, L., \& Lubim, D. (1996). The life history of the tropical shad tenualosa toli from Sarawak: First evidence of protandry in the clupeiformes. Environmental Biology of Fishes, 46(3), 225-242. https://doi.org/10.1007/BF00004998

Blaber, S. J., Milton, D. A., Chenery, S. R., \& Fry, G. (2003). New insights into the life history of Tenualosa ilisha and fishery implications. American Fisheries Society, 35, 223-240.

$\begin{array}{llll}\text { Google } & \text { maps. } & \text { (2019). } & \text { Retrieved }\end{array}$ https://www.google.com/maps/search/google+maps/@1.430272,110.9294545,141183m/data $=! 3 \mathrm{~m} 1 ! 1 \mathrm{e} 3$

Philip, W. P. (2001). The status of terubok (tenualosa toli) fishery in Sarawak. International Terubok Conference. In Proceedings of the International Terubok Conference Sarawak, Malaysia, 91-99.

Rahim, K. A. A., Tumiran, M. H., Long, S. M., Yuzine, E., \& Husaini, A. (2014). The status of tenualosa toli in the southwest coast of Sarawak, Malaysia. Kuroshio Science, 8(1), 39-44. 


\section{Macrothink}

Journal of Public Administration and Governance ISSN 2161-7104 2019, Vol. 9, No. 3

Rajali, H. (1991). Perikanan Terubuk (Tenualosa toli) di Sarawak, Malaysia. K. P. Jabatan Perikanan, Ed.

\section{Copyright Disclaimer}

Copyright for this article is retained by the author(s), with first publication rights granted to the journal.

This is an open-access article distributed under the terms and conditions of the Creative Commons Attribution license (http://creativecommons.org/licenses/by/4.0/). 